\title{
Methylobacterium populi sp. nov., a novel aerobic, pink-pigmented, facultatively methylotrophic, methane-utilizing bacterium isolated from poplar trees (Populus deltoides $\times$ nigra DN34)
}

\author{
Benoit Van Aken, ${ }^{1}$ Caroline M. Peres, ${ }^{2} \uparrow$ Sharon Lafferty Doty, ${ }^{3}$ \\ Jong Moon Yoon ${ }^{1}$ and Jerald L. Schnoor ${ }^{1}$ \\ ${ }^{1}$ Department of Civil and Environmental Engineering, University of lowa, 4105 Seamans \\ Center, lowa City, IA 52242, USA \\ ${ }^{2}$ Department of Microbiology, University of lowa, 3-432 Bowen Science Building, lowa City, \\ IA 52242, USA \\ ${ }^{3}$ Department of Biochemistry, Box 357350, University of Washington, Seattle, WA 98195, USA
}

Correspondence

Benoit Van Aken bvanaken@engineering. uiowa.edu

\begin{abstract}
A pink-pigmented, aerobic, facultatively methylotrophic bacterium, strain $\mathrm{BJ} 001^{\top}$, was isolated from internal poplar tissues (Populus deltoides $\times$ nigra DN34) and identified as a member of the genus Methylobacterium. Phylogenetic analyses showed that strain $\mathrm{BJ} 001^{\top}$ is related to Methylobacterium thiocyanatum, Methylobacterium extorquens, Methylobacterium zatmanii and Methylobacterium rhodesianum. However, strain $\mathrm{BJ} 001^{\top}$ differed from these species in its carbon-source utilization pattern, particularly its use of methane as the sole source of carbon and energy, an ability that is shared with only one other member of the genus, Methylobacterium organophilum. In addition, strain $\mathrm{BJ} 001^{\top}$ is the only member of the genus Methylobacterium to be described as an endophyte of poplar trees. On the basis of its physiological, genotypic and ecological properties, the isolate is proposed as a member of a novel species of the genus Methylobacterium, Methylobacterium populi sp. nov. (type strain, $B J 001^{\top}=$ ATCC BAA $-705^{\top}=$ NCIMB $13946^{\top}$ ).
\end{abstract}

Species of the genus Methylobacterium are strictly aerobic, facultatively methylotrophic, Gram-negative, rod-shaped bacteria that are able to grow on one-carbon compounds (e.g. methanol or methylamine), as well as on a variety of $\mathrm{C}_{2}, \mathrm{C}_{3}$ and $\mathrm{C}_{4}$ substrates (Green, 1992). Only the type species, Methylobacterium organophilum, has been shown to use methane as the sole source of carbon and energy (Patt et al., 1976). The genus Methylobacterium belongs to

Published online ahead of print on 20 February 2004 as DOI 10.1099/ ijs.0.02796-0.

†Present address: Genencor International, 925 Page Mill Road, Palo Alto, CA 94304, USA.

Abbreviations: IGS, intergenic spacer; SEM, scanning electron microscope. The GenBank/EMBL/DDBJ accession number for the $16 \mathrm{~S}$ and 16S$23 S$ IGS rDNA sequence of strain $B J 001^{\top}$ is AY251818.

Tissue culture images, photomicrographs, 16S and 16S-23S IGS rDNA sequences of $\mathrm{BJOO1}^{\top}$, sequence similarity matrices, carbon- and nitrogen-source utilization data and enzymic reactions of $\mathrm{BJO0}{ }^{\top}$ are available as supplementary material in IJSEM Online.

Dedicated to Olivier Van Aken (1964-1980). the $\alpha 2$ subclass of the Proteobacteria and currently consists of 14 species with validly published names (Heumann, 1962; Ito \& Iizuka, 1971; Kouno \& Ozaki, 1975; Patt et al., 1976; Rock et al., 1976; Austin \& Goodfellow, 1979; Green \& Bousfield, 1983; Urakami \& Komagata, 1984; Bousfield \& Green, 1985; Green et al., 1988; Urakami et al., 1993; Wood et al., 1998; Doronina et al., 2000, 2002; McDonald et al., 2001; Sy et al., 2001). Members of the genus Methylobacterium are distributed in a wide variety of natural and man-made environments, including soil, air, dust, freshand marine water and sediments, water supplies, bathrooms, air-conditioning systems and masonry (Hiraishi et al., 1995; Trotsenko et al., 2001). Some species have been described as opportunistic human pathogens (Truant et al., 1998; Hornei et al., 1999). In addition, methylotrophic bacteria are frequently associated with terrestrial and aquatic plants, where they colonize roots and leaf surfaces (Austin et al., 1978; Yoshimura, 1982; Corpe \& Rheem, 1989; Trotsenko et al., 2001; Lidstrom \& Chistoserdova, 2002). The association of Methylobacterium species with plants seems to rely on a symbiotic relationship between the bacterium and the plant host. Plants produce methanol 
(representing nearly $50 \%$ of the total volatile atmospheric organic carbon), which is toxic and is used by Methylobacterium species as the sole source of carbon and energy (i.e. the methanol cycle; Trotsenko et al., 2001). In response, Methylobacterium species produce phytohormones (cytokinins and auxins), which are known to stimulate plant growth (Ivanova et al., 2001; Koenig et al., 2002), fix atmospheric nitrogen (Sy et al., 2001) or help plants to fight pathogens (Holland \& Polacco, 1994). Bacteria are often pink to red, due to the presence of carotenoids, and are referred to as pink-pigmented facultative methylotrophs. Members of the genus Methylobacterium are highly resistant to dehydration, freezing, chlorine, UV and ionizing radiation and elevated temperatures (Trotsenko et al., 2001). Methylobacterium species are known to metabolize a range of toxic organic chemicals, such as methyl chloride (McDonald et al., 2001), methyl bromide (Goodwin et al., 2001), methyl iodide (Schaefer \& Oremland, 1999), dichloromethane (Doronina et al., 2000), ethylated sulfurcontaining compounds (de Zwart et al., 1996), methylated amines (Trotsenko et al., 2001), methyl tert-butyl ether (Mo et al., 1997) and cyanate and thiocyanate (Wood et al., 1998). In this paper, the formal taxonomic description of a novel Methylobacterium strain, BJ001 ${ }^{\mathrm{T}}$, isolated from poplar tissues and able to use methane as the sole source of carbon and energy, is reported.

Methylobacterium sp. strain $\mathrm{BJ}_{001^{\mathrm{T}}}$ was isolated from poplar plantlets and from tissue cultures (Populus deltoides $\times$ nigra DN34) that were developed initially from surfacesterilized explants and maintained under axenic conditions (Van Aken \& Schnoor, 2002). Images of tissue cultures containing strain $\mathrm{BJ} 001^{\mathrm{T}}$ are available in Supplementary Fig. A in IJSEM Online. Poplar plantlets were surfacesterilized before bacterial isolation. The isolated bacterium was maintained routinely on Luria-Bertani (LB) medium, supplemented with fructose $\left(5 \mathrm{~g} \mathrm{l}^{-1}\right)$, or on selective methanol mineral medium (Green, 1992). Morphological properties were studied according to general protocols (Gerhardt et al., 1994). Scanning electron microscope (SEM) observations were performed on fixed material that was prepared for routine examination by glutaraldehyde fixation, osmium tetroxide post-fixation and graded ethanol dehydration (Bozzola \& Russell, 1998). Samples were critical point-dried, mounted on stubs, sputter-coated with gold/palladium and visualized by using a Hitachi S-4000 SEM equipped with a field-emission electron source. Carbon-source utilization tests were performed by using a standard protocol described by Green \& Bousfield (1982). Cellular fatty acids were extracted according to Bligh \& Dyer (1959), purified on Sephadex beads (Amersham Biosciences) and analysed by GC-mass spectroscopy (Gerhardt et al., 1994). DNA G +C content was determined by HPLC analysis of individual nucleosides, resulting from DNA hydrolysis and dephosphorylation (Mesbah et al., 1989). DNA manipulations were carried out according to standard protocols (Ausubel et al., 1999; Sambrook \& Russell, 2000). 16S and 16S-23S intergenic spacer (IGS) rDNA analyses were performed by PCR amplification using the following primers: $27 \mathrm{f}$ (positions 11-27 of bacterial 16S rDNA, Escherichia coli numbering), 1522r (positions 1492-1522), 926f (positions 901-926) and 115r/23S (positions 97-115 of bacterial 23S rDNA, E. coli numbering) (Hurek et al., 1997; Tan et al., 2001). PCR conditions were as described by Tan et al. (2001). PCR products were cloned in a pGEM vector (Promega) and submitted to the University of Iowa DNA Core (Iowa City, IA, USA) for sequencing. Determined rDNA and reference sequences from GenBank were aligned by using CLUSTAL_W multiple alignment and BIOEDIT (version 5.0.9) software. The tree topology was inferred by the parsimony method (heuristic search) using PAUP (version 4.0) software (Sinauer Associates). DNA-DNA hybridization was carried out according to Doronina et al. (2002), using a method based on that of Denhardt (1966). Unlabelled, denatured DNA of Methylobacterium species was immobilized on nitrocellulose membranes (Bio-Rad) (Ausubel et al., 1999; Sambrook \& Russell, 2000). Reference DNA from strain $\mathrm{BJ} 001^{\mathrm{T}}$ was labelled with deoxy $\left[1^{\prime}, 2^{\prime}, 5-^{3} \mathrm{H}\right]$ cytidine $5^{\prime}$ triphosphate $\quad\left(57 \mathrm{Ci} \mathrm{mmol}^{-1}=2 \cdot 1 \times 10^{6} \mathrm{MBq} \mathrm{mmol}^{-1}\right)$ by using a Nick Translation kit (N5500; Amersham Biosciences). After labelling, reference DNA exhibited a specific activity of $1.47 \times 10^{5} \mathrm{~Bq} \mathrm{gg}^{-1}$ and a mean size of 400-600 bp (as determined on $2 \cdot 0 \%$ agarose gel). Labelled DNA was denatured at $100^{\circ} \mathrm{C}$ for $10 \mathrm{~min}$. Hybridization was performed according to Denhardt (1966), with a ratio of labelled to immobilized DNA of 1:100 (Doronina et al., 2002). Low-stringency (pre)-hybridization solution consisted of $30 \%(\mathrm{v} / \mathrm{v})$ formamide, $1 \times$ SSC, $5 \times$ Denhardt's solution, $1.0 \%$ SDS and $100 \mu \mathrm{g}$ denatured salmon sperm DNA $\mathrm{ml}^{-1}$. Radioactivity retained on the membrane was determined by liquid scintillation counting.

The bacterium isolated from poplar tissues, strain $\mathrm{BJ} 001^{\mathrm{T}}$, was identified by phylogenetic analysis as a member of the genus Methylobacterium (Fig. 1). Members of this genus are known to colonize the rhizosphere and phyllosphere of a variety of plant species (Austin et al., 1978; Yoshimura, 1982; Corpe \& Rheem, 1989; Holland \& Polacco, 1994; Trotsenko et al., 2001). However, this is the first report of an endophytic association with a poplar tree (Populus sp.). The isolate had the following characteristics of the genus Methylobacterium (Green, 1992). Cells were rodshaped $(0 \cdot 8-1 \cdot 0 \times 1 \cdot 0-10 \cdot 0 \mu \mathrm{m})$, frequently branched and occurred singly or in rosettes (Fig. 2). They exhibited polar growth and were motile by a single polar or lateral flagellum. Photomicrographs of strain $\mathrm{BJ} 001^{\mathrm{T}}$ are available in Supplementary Figs B and C in IJSEM Online. Cells stained Gram-negative and colonies were pink to red. Cells were strictly aerobic and catalase- and oxidase-positive (Gerhardt et al., 1994). Due to the chemotaxonomic homogeneity of the genus Methylobacterium, phylogenetic analyses constitute a critical tool for species identification (Green \& Bousfield, 1982; Doronina et al., 2002). According to $16 \mathrm{~S}$ rDNA sequences, the closest relatives of strain $\mathrm{BJ} 001^{\mathrm{T}}$ were Methylobacterium thiocyanatum, Methylobacterium 


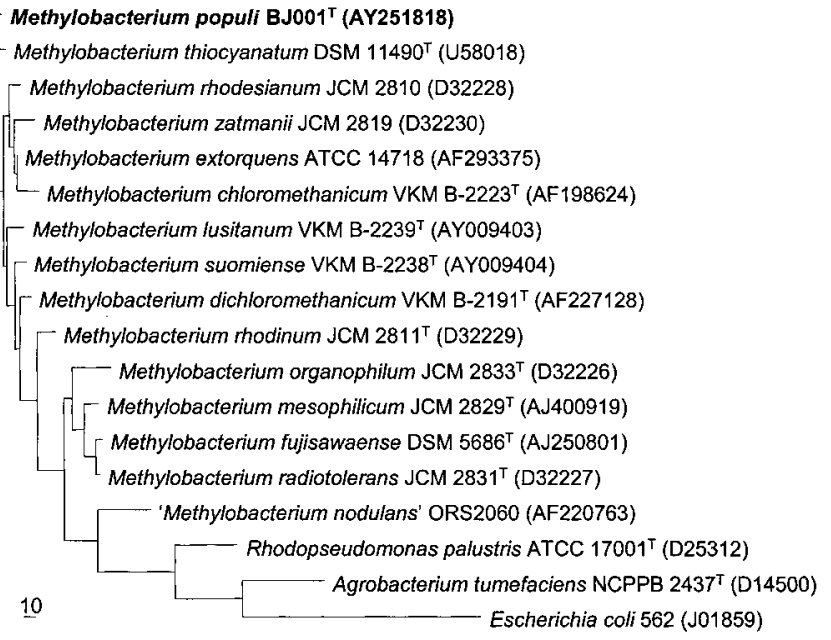

Fig. 1. Phylogenetic tree based on $16 \mathrm{~S}$ rDNA sequences of members of the genus Methylobacterium and other representatives of the Proteobacteria, showing the location of strain $\mathrm{BJO01}{ }^{\top}$. GenBank accession numbers are provided in parentheses. Distances reflect the number of pairwise character differences.

extorquens, Methylobacterium zatmanii and Methylobacterium rhodesianum, with $99 \cdot 3$, 99.1, $98 \cdot 6$ and $98 \cdot 5 \%$ $16 \mathrm{~S}$ rDNA sequence similarity, respectively, corresponding to the interspecies separation level of the genus Methylobacterium (94.2-99.4\%; Doronina et al., 2002). On the basis of $16 \mathrm{~S}-23 \mathrm{~S}$ IGS rDNA sequences, strain $\mathrm{BJ} 001^{\mathrm{T}}$ shared $78 \cdot 7-82 \cdot 1 \%$ similarity with $M$. extorquens (GenBank accession nos AF293375 and AF338180) and $66.5 \%$ similarity with the type species, M. organophilum (GenBank accession no. AF338181). The 16S and 16S-23S IGS rDNA sequence of strain $\mathrm{BJ} 001^{\mathrm{T}}$ and sequence similarity matrices are available in Supplementary Tables A

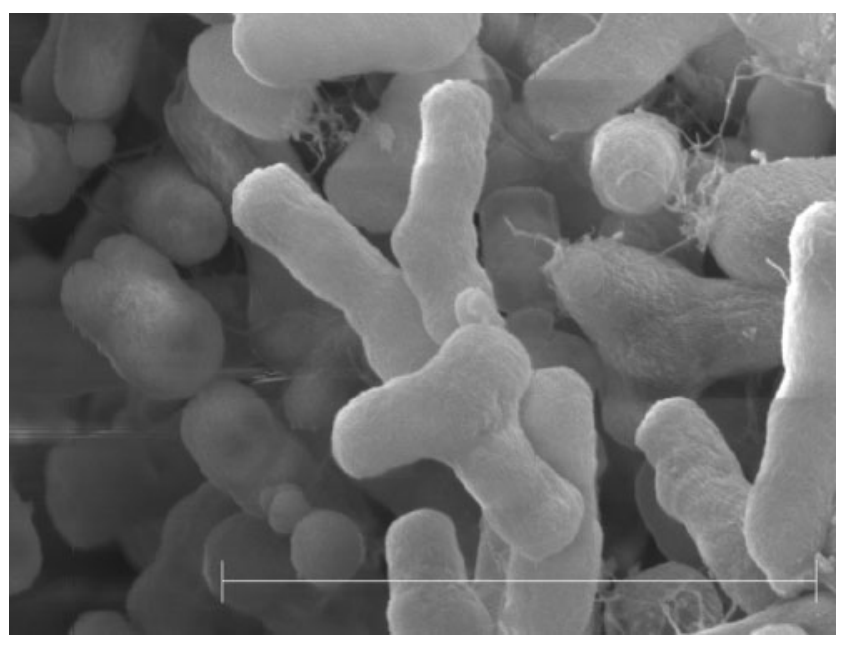

Fig. 2. Scanning electron micrograph of strain $\mathrm{BJ} 001^{\top}$ isolated from Populus deltoides $\times$ nigra DN34. Bar, 5.0 $\mu \mathrm{m}$. and B in IJSEM Online. Levels of DNA relatedness between strain $\mathrm{BJ} 001^{\mathrm{T}}$ and its closest relatives, as determined by DNA-DNA hybridization, were 15-59\%, which indicates that strain $\mathrm{BJ} 001^{\mathrm{T}}$ can be separated from other members of the genus Methylobacterium (Table 1). Phenotypic differences between Methylobacterium species are limited and often rely on utilization of carbon and energy sources (Green, 1992). Like other members of the genus, strain BJ001 ${ }^{\mathrm{T}}$ grew on $\mathrm{C}_{1}$ substrates, such as methanol, methylamine, formate and formaldehyde. In addition, strain $\mathrm{BJ} 001^{\mathrm{T}}$ utilized methane, an ability that is shared with only one other species of the genus, M. organophilum (Patt et al., 1976). Strain $B J 001^{\mathrm{T}}$ may play an important ecological role by consuming methane, the greenhouse effect of which is 20 times higher than that of carbon dioxide (Trotsenko et al., 2001). Strain BJ001 $1^{\mathrm{T}}$ differed from its closest relatives (i.e. M. thiocyanatum, M. extorquens, M. zatmanii and M. rhodesianum) in several other carbon-source utilization features (summarized in Table 2). M. thiocyanatum grows on glucose, arabinose, glutamate, citrate, cyanate and thiocyanate, M. zatmanii grows on trimethylamine and M. rhodesianum grows on dimethylamine, none of which support growth of strain $\mathrm{BJ} 001^{\mathrm{T}}$. On the other hand, M. extorquens does not use fructose, M. zatmanii does not use betaine and $M$. rhodesianum does not use tartrate, all of which are substrates for strain BJ001 ${ }^{\mathrm{T}}$ (Rock et al., 1976; Urakami \& Komagata, 1984; Green, 1992; Wood et al., 1998). Fructose, the first hexose synthesized by plant photosynthesis, was by far the best carbon substrate for strain $\mathrm{BJ} 001^{\mathrm{T}}$, which may be related to its association with poplar trees. Tables of carbon- and nitrogen-source utilization and enzymic reactions of $\mathrm{BJ} 001^{\mathrm{T}}$ are available as Supplementary Tables D, E and F in IJSEM Online.

Strain $\mathrm{BJ} 001^{\mathrm{T}}$ has been shown to mineralize the toxic explosives hexahydro-1,3,5-trinitro-1,3,5-triazine (RDX) and octahydro-1,3,5,7-tertanitro-1,3,5,7-tetrazocine (HMX),

Table 1. DNA-DNA hybridization values between Methylobacterium populi $\mathrm{BJOO1^{ \top }}$ and its closest relatives

The hybridization procedure was carried out according to the method of Denhardt (1966).

\begin{tabular}{|c|c|}
\hline Species & $\begin{array}{c}\text { DNA-DNA } \\
\text { hybridization (\%) }\end{array}$ \\
\hline Methylobacterium populi $\mathrm{BJ} 001^{\mathrm{T}}$ & 100 \\
\hline Methylobacterium thiocyanatum DSM $11490^{\mathrm{T}}$ & 47 \\
\hline Methylobacterium extorquens ATCC 14718 & 59 \\
\hline Methylobacterium zatmanii JCM 2819 & 34 \\
\hline Methylobacterium rhodesianum JCM 2810 & 25 \\
\hline Methylobacterium suomiense VKM B- $2238^{\mathrm{T}}$ & 33 \\
\hline Methylobacterium lusitanum VKM B- $2239^{\mathrm{T}}$ & 15 \\
\hline Methylobacterium organophilum JCM $2833^{\mathrm{T}}$ & 28 \\
\hline Agrobacterium tumefaciens NCPPB $2437^{\mathrm{T}}$ & 7 \\
\hline
\end{tabular}


Table 2. Differential carbon-substrate utilization among Methylobacterium species

Utilization of various compounds as sole sources of carbon and energy is shown. Adapted from Green (1992). Species: 1, BJ001 ${ }^{\mathrm{T}}$; 2, M. aminovorans (Urakami et al., 1993); 3, M. chloromethanicum (McDonald et al., 2001); 4, M. dichloromethanicum (Doronina et al., 2000); 5, M. extorquens (Urakami \& Komagata, 1984); 6, M. fujisawaense (Kouno \& Ozaki, 1975); 7, M. lusitanum (Doronina et al., 2002); 8, M. mesophilicum (Austin \& Goodfellow, 1979); 9, M. organophilum (Patt et al., 1976); 10, M. radiotolerans (Ito \& Iizuka, 1971); 11, M. rhodesianum (Rock et al., 1976); 12, M. rhodinum (Heumann, 1962); 13, M. suomiense (Doronina et al., 2002); 14, M. thiocyanatum (Wood et al., 1998); 15, M. zatmanii (Rock et al., 1976). +, Growth; -, no growth; V, variable; W, weak growth; ND, not determined.

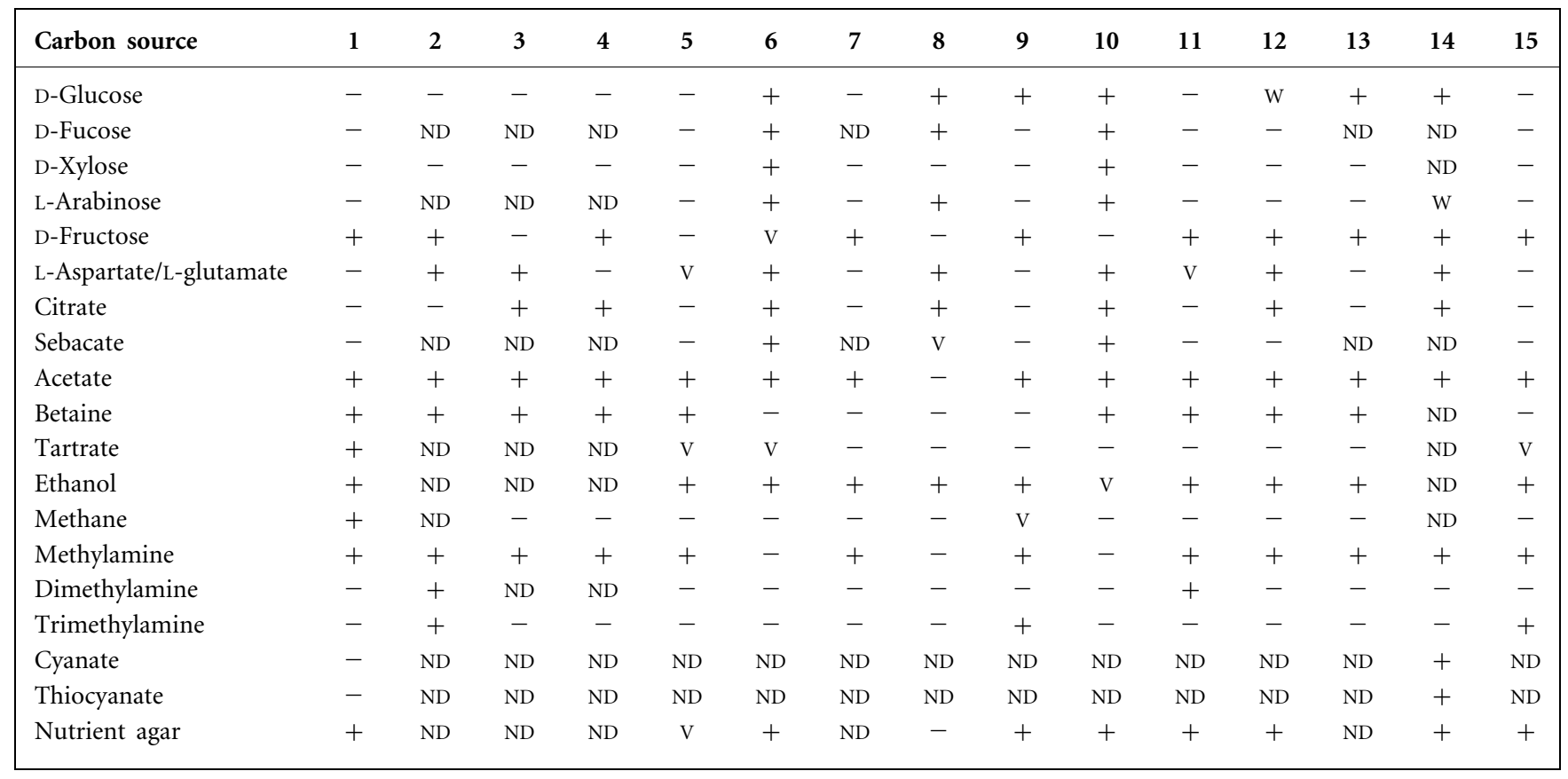

which contaminate numerous military sites in the USA, to $\mathrm{CO}_{2}$ (data not shown). Whereas this extends the list of organic pollutants that are potentially biodegraded by Methylobacterium species, this particular ability has not been tested among other members of the genus and cannot be regarded as a diagnostic test. According to their widespread distribution in a diversity of environments, Methylobacterium species may be suited for natural attenuation or in situ bioremediation (including phytoremediation) of polluted sites.

On the basis of its $16 \mathrm{~S}$ and 16S-23S IGS rDNA sequence similarity data, DNA-DNA hybridization values, carbonsource utilization pattern (including the use of methane) and endophytic association with poplar trees, strain $\mathrm{BJ} 001^{\mathrm{T}}$ is proposed as the type strain of a novel Methylobacterium species, with the name Methylobacterium populi sp. nov.

\section{Description of Methylobacterium populi sp. nov.}

Methylobacterium populi (po'pu.li. L. gen. n. populi of poplar).

Cells are aerobic, Gram-negative, asporogenous rods $(0 \cdot 8-$ $1 \cdot 0 \times 1 \cdot 0-10 \cdot 0 \mu \mathrm{m})$ that occur singly, in pairs or in rosettes. Cells are motile by one single polar or lateral flagellum. Colonies are pink to red, slow-growing and $0 \cdot 1-0 \cdot 2 \mathrm{~mm}$ in diameter after 4 days at $28{ }^{\circ} \mathrm{C}$ on $\mathrm{LB}$ or nutrient agar (NA) plates. The pink pigment is water-insoluble and has absorption maxima at 390, 473, 505 and $534 \mathrm{~nm}$ in chloroform/ methanol $(1: 1)$. Positive for the following enzymic reactions: catalase, oxidase, alkaline phosphatase, esterases $\left(\mathrm{C}_{4}\right.$ and $C_{8}$ ), valine arylamidase, $\alpha$-chymotrypsin, acid phosphatase and naphthol-AS-BI-phosphohydrolase. Carbon sources utilized are D-fructose, glycerol, methanol, ethanol, formate, acetate, succinate, lactate, tartrate, pyruvate, fumarate, salicylate, formaldehyde, methylamine, methane and betaine. Grows on LB and NA plates at $28^{\circ} \mathrm{C}$. Does not use D- or L-arabinose, D-fucose, D-galactose, D-glucose, D-lactose, D-mannose, D-xylose, sucrose, propan-2-ol, n-butanol, inositol, mannitol, sorbitol, L-aspartate, L-glutamate, glycine, citrate, sebacate, dimethylamine, trimethylamine, chloromethane, dichloromethane, cyanate or thiocyanate. Nitrogen sources utilized are ammonium, nitrate, L-alanine, L-aspartate, L-glutamate, L-glutamine, glycine, L-tryptophan and methylamine. Cellular fatty acids are: hexadecanoate (palmitic acid, $\mathrm{C}_{16: 0}$ ), $6 \cdot 4 \pm 0 \cdot 4 \%$ $(n=3)$; cis-9-octadecenoate (oleic acid, $\mathrm{C}_{18: 1} 9$ ), $81 \cdot 6 \pm 2 \cdot 1 \%$ $(n=3)$; and octadecanoate (stearic acid, $\left.\mathrm{C}_{18: 0}\right), 11 \cdot 9 \pm 0 \cdot 3 \%$ $(n=3)$. Optimal $\mathrm{pH}$ for growth is $7 \cdot 0$; does not grow at $\mathrm{pH} 4.0$ or $9 \cdot 0$. Optimal temperature for growth is $20-30{ }^{\circ} \mathrm{C}$; does not grow at 15 or $40{ }^{\circ} \mathrm{C}$. Does not grow in the presence of $2.0 \% \mathrm{NaCl}$. DNA G+C content is $70 \cdot 4 \pm 0 \cdot 3 \mathrm{~mol} \%(n=3)$. 
The type strain, BJ001 ${ }^{\mathrm{T}}\left(=\mathrm{ATCC}\right.$ BAA $-705^{\mathrm{T}}=\mathrm{NCIMB}$ $13946^{\mathrm{T}}$ ), was isolated from internal poplar tissues (Populus deltoides $\times$ nigra DN34) obtained from Hramoor Nursery (Manistee, MI, USA).

\section{Acknowledgements}

This is a contribution of the W. M. Keck Phytotechnology Laboratory at the University of Iowa, supported by a gift from the W. M. Keck Foundation. We thank SERDP (Strategic Environmental Research and Development Program award number 02 CU13-17) for financial support. We acknowledge C. S. Harwood (University of Iowa, IA, USA) and M. E. Lidstrom (University of Washington, WA, USA) for relevant discussion.

\section{References}

Austin, B. \& Goodfellow, M. (1979). Pseudomonas mesophilica, a new species of pink bacteria isolated from leaf surfaces. Int J Syst Bacteriol 29, 373-378.

Austin, B., Goodfellow, M. \& Dickinson, C. H. (1978). Numerical taxonomy of phylloplane bacteria isolated from Lolium perenne. J Gen Microbiol 104, 139-155.

Ausubel, F. M., Brent, R., Kingston, R. E., Moore, D. D., Seidman, J. G., Smith, J. A. \& Struhl, K. (1999). Current Protocols in Molecular Biology, 4th edn. New York: Wiley.

Bligh, E. G. \& Dyer, W. J. (1959). A rapid method of total lipid extraction and purification. Can J Med Sci 37, 911-917.

Bousfield, I. J. \& Green, P. N. (1985). Reclassification of bacteria of the genus Protomonas Urakami and Komagata 1984 in the genus Methylobacterium (Patt, Cole, and Hanson) emend. Green and Bousfield 1983. Int J Syst Bacteriol 35, 209.

Bozzola, J. J. \& Russell, L. D. (1998). Electron Microscopy, 2nd edn. Sudbury, MS: Jones \& Bartlett.

Corpe, W. A. \& Rheem, S. (1989). Ecology of the methylotrophic bacteria on living leaf surfaces. FEMS Microbiol Ecol 62, $243-250$.

Denhardt, D. T. (1966). A membrane-filter technique for the detection of complementary DNA. Biochem Biophys Res Commun 23, 641-646.

de Zwart, J. M. M., Nelisse, P. N. \& Kuenen, J. G. (1996). Isolation and characterization of Methylophaga sulfidovorans sp. nov.: an obligately methylotrophic, aerobic, dimethylsulfide oxidizing bacterium from a microbial mat. FEMS Microbiol Ecol 20, 261-270.

Doronina, N. V., Trotsenko, Y. A., Tourova, T. P., Kuznetsov, B. B. \& Leisinger, T. (2000). Methylopila helvetica sp. nov. and Methylobacterium dichloromethanicum sp. nov. - novel aerobic facultatively methylotrophic bacteria utilizing dichloromethane. Syst Appl Microbiol 23, 210-218.

Doronina, N. V., Trotsenko, Y. A., Kuznetsov, B. B., Tourova, T. P. \& Salkinoja-Salonen, M. S. (2002). Methylobacterium suomiense sp. nov. and Methylobacterium lusitanum sp. nov., aerobic, pinkpigmented, facultatively methylotrophic bacteria. Int J Syst Evol Microbiol 52, 773-776.

Gerhardt, P. R., Murray, R. G. E., Wood, W. A. \& Krieg, N. R. (editors) (1994). Methods for General and Molecular Bacteriology. Washington, DC: American Society for Microbiology.

Goodwin, K. D., Varner, R. K., Crill, P. M. \& Oremland, R. S. (2001). Consumption of tropospheric levels of methyl bromide by $\mathrm{C}_{1}$ compound-utilizing bacteria and comparison to saturation kinetics. Appl Environ Microbiol 67, 5437-5443.
Green, P. N. (1992). The genus Methylobacterium. In The Prokaryotes, 2nd edn, pp. 2342-2349. Edited by A. Balows, H. G. Trüper, M. Dworkin, W. Harder \& K.-H. Schleifer. New York: Springer.

Green, P. N. \& Bousfield, I. J. (1982). A taxonomic study of some Gram-negative facultatively methylotrophic bacteria. J Gen Microbiol 128, 623-638.

Green, P. N. \& Bousfield, I. J. (1983). Emendation of Methylobacterium Patt, Cole, and Hanson 1976; Methylobacterium rhodinum (Heumann 1962) comb. nov. corrig.; Methylobacterium radiotolerans (Ito and Iizuka 1971) comb. nov. corrig.; and Methylobacterium mesophilicum (Austin and Goodfellow 1979) comb. nov. Int J Syst Bacteriol 33, 875-877.

Green, P. N., Bousfield, I. J. \& Hood, D. (1988). Three new Methylobacterium species: M. rhodesianum sp. nov., M. zatmanii sp. nov., and M. fujisawaense sp. nov. Int J Syst Bacteriol 38, 124-127.

Heumann, W. (1962). Die Methodik der Kreuzung sternbildender Bakterien. Biol Zentbl 81, 341-354 (in German).

Hiraishi, A., Furuhata, K., Matsumoto, A., Koike, K. A., Fukuyama, M. \& Tabuchi, K. (1995). Phenotypic and genetic diversity of chlorineresistant Methylobacterium strains isolated from various environments. Appl Environ Microbiol 61, 2099-2107.

Holland, M. A. \& Polacco, J. C. (1994). PPFMs and other covert contaminants: is there more to plant physiology than just plant? Annu Rev Plant Physiol Plant Mol Biol 45, 197-209.

Hornei, B., Lüneberg, E., Schmidt-Rotte, H., Maaß, M., Weber, K., Heits, F., Frosch, M. \& Solbach, W. (1999). Systemic infection of an immunocompromised patient with Methylobacterium zatmanii. J Clin Microbiol 37, 248-250.

Hurek, T., Wagner, B. \& Reinhold-Hurek, B. (1997). Identification of $\mathrm{N}_{2}$-fixing plant- and fungus-associated Azoarcus species by PCR-based genomic fingerprints. Appl Environ Microbiol 63, 4331-4339.

Ito, H. \& lizuka, H. (1971). Taxonomic studies on a radio-resistant Pseudomonas. XII. Studies on the microorganisms of cereal grain. Agric Biol Chem 35, 1566-1571.

Ivanova, E. G., Doronina, N. V. \& Trotsenko, Y. A. (2001). Aerobic methylobacteria are capable of synthesizing auxins. Microbiologiya 70, 452-458 (in Russian).

Koenig, R. L., Morris, R. O. \& Polacco, J. C. (2002). tRNA is the source of low-level trans-zeatin production in Methylobacterium spp. J Bacteriol 184, 1832-1842.

Kouno, K. \& Ozaki, A. (1975). Distribution of methanol-utilizing bacteria. In Proceedings of the International Symposium on Microbial Growth on $C_{1}$ Compounds, pp. 11-21. Osaka, Japan: Society of Fermentation Technology.

Lidstrom, M. E. \& Chistoserdova, L. (2002). Plants in the pink: cytokinin production by Methylobacterium. J Bacteriol 184, 1818.

McDonald, I. R., Doronina, N. V., Trotsenko, Y. A., McAnulla, C. \& Murrell, J. C. (2001). Hyphomicrobium chloromethanicum sp. nov. and Methylobacterium chloromethanicum sp. nov., chloromethaneutilizing bacteria isolated from a polluted environment. Int J Syst Evol Microbiol 51, 119-122.

Mesbah, M., Premachandran, U. \& Whitman, W. B. (1989). Precise measurement of the $\mathrm{G}+\mathrm{C}$ content of deoxyribonucleic acid by high-performance liquid chromatography. Int J Syst Bacteriol 39, 159-167.

Mo, K., Lora, C. O., Wanken, A. E., Javanmardian, M., Yang, X. \& Kulpa, C. F. (1997). Biodegradation of methyl $t$-butyl ether by pure bacterial cultures. Appl Microbiol Biotechnol 47, 69-72.

Patt, T. E., Cole, G. C. \& Hanson, R. S. (1976). Methylobacterium, a new genus of facultatively methylotrophic bacteria. Int $J$ Syst Bacteriol 26, 226-229. 
Rock, J. S., Goldberg, I., Ben-Bassat, A. \& Mateles, R. I. (1976). Isolation and characterization of two methanol-utilizing bacteria. Agric Biol Chem 40, 2129-2135.

Sambrook, J. \& Russell, D. (2000). Molecular Cloning: a Laboratory Manual, 3rd edn. Cold Spring Harbor, NY: Cold Spring Harbor Laboratory.

Schaefer, J. K. \& Oremland, R. S. (1999). Oxidation of methyl halides by the facultative methylotroph strain IMB-1. Appl Environ Microbiol 65, 5035-5041.

Sy, A., Giraud, E., Jourand, P. \& 8 other authors (2001). Methylotrophic Methylobacterium bacteria nodulate and fix nitrogen in symbiosis with legumes. J Bacteriol 183, 214-220.

Tan, Z., Hurek, T., Vinuesa, P., Muller, P., Ladha, J. K. \& ReinholdHurek, B. (2001). Specific detection of Bradyrhizobium and Rhizobium strains colonizing rice (Oryza sativa) roots by $16 \mathrm{~S}-23 \mathrm{~S}$ ribosomal DNA intergenic spacer-targeted PCR. Appl Environ Microbiol 67, 3655-3664.

Trotsenko, Y. A., Ivanova, E. G. \& Doronina, N. V. (2001). Aerobic methylotrophic bacteria as phytosymbionts. Mikrobiologiya 70, 725736 (in Russian).
Truant, A. L., Gulati, R., Giger, O., Satishchandran, V. \& Caya, J. G. (1998). Methylobacterium species: an increasingly important opportunistic pathogen. Lab Med 29, 704-710.

Urakami, T. \& Komagata, K. (1984). Protomonas, a new genus of facultatively methylotrophic bacteria. Int J Syst Bacteriol 34, 188-201.

Urakami, T., Araki, H., Suzuki, K. \& Komagata, K. (1993). Further studies of the genus Methylobacterium and description of Methylobacterium aminovorans sp. nov. Int J Syst Bacteriol 43, 504-513.

Van Aken, B. \& Schnoor, J. L. (2002). Evidence of perchlorate $\left(\mathrm{CLO}_{4}^{-}\right)$reduction in plant tissues (poplar tree) using radio-labeled ${ }^{35} \mathrm{CLO}_{4}^{-}$. Environ Sci Technol 36, 2783-2788.

Wood, A. P., Kelly, D. P., McDonald, I. R., Jordan, S. L., Morgan, T. D., Khan, S., Murrell, J. C. \& Borodina, E. (1998). A novel pinkpigmented facultative methylotroph, Methylobacterium thiocyanatum sp. nov., capable of growth on thiocyanate or cyanate as sole nitrogen sources. Arch Microbiol 169, 148-158.

Yoshimura, F. (1982). Phylloplane bacteria in a pine forest. Can J Microbiol 28, 580-592. 